The Death and Life of Drama 


\section{Previous Works}

PLAYS

Time's Up and Other Plays

Time's Up

Fox, Hound, and Huntress

POETRY

Becoming Human

Wrestling with the Angel

NOVELS

Second Chances

NONFICTION

A Poetics for Screenwriters

The Understructure of Writing for Film and Television (with Ben Brady) 


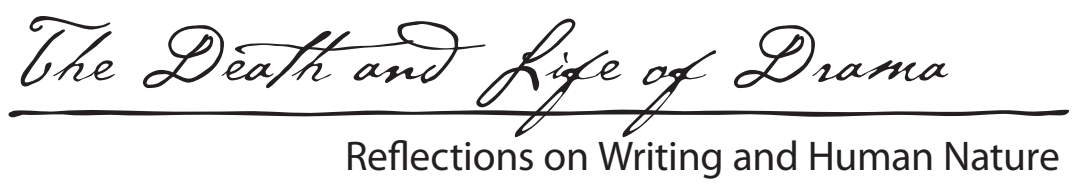

L A NCE LEE

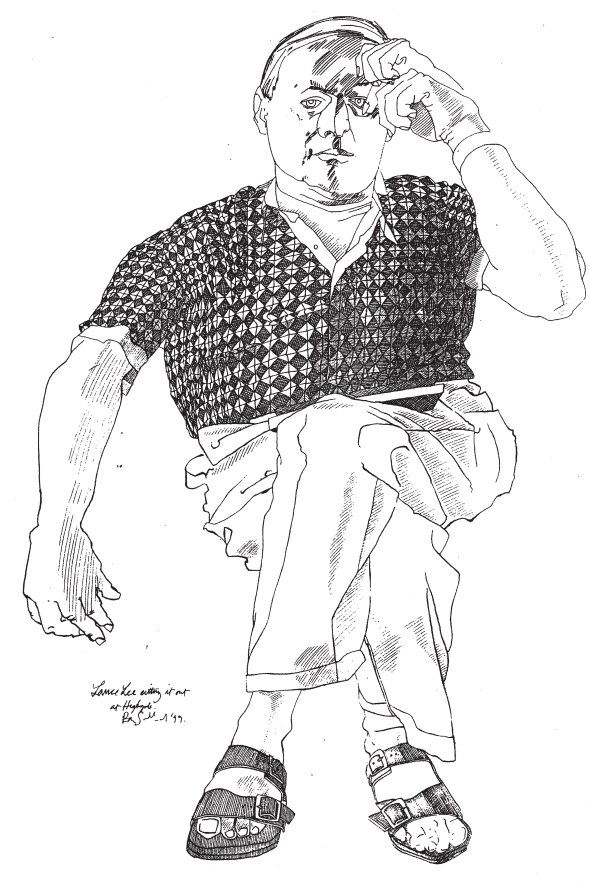

$\hookrightarrow$ University OF TEXAs PRESS Austin 
Copyright $(2) 2005$ by the University of Texas Press

All rights reserved

Printed in the United States of America

First edition, 2005

Requests for permission to reproduce material from this work should be sent to:

Permissions

University of Texas Press

P.O. Box 7819

Austin, TX 78713-7819

www.utexas.edu/utpress/about/bpermission.html

(0) The paper used in this book meets the minimum requirements

of ANSI/NISO Z39.48-1992 (R1997) (Permanence of Paper).

LIBRARY OF CONGRESS CATALOGING-IN-PUBLICATION DATA

Lee, Lance, $1942-$

The death and life of drama : reflections on writing and human nature / Lance Lee-1st ed.

p. $\quad \mathrm{cm}$.

IS B N 0-292-70532-8 (cloth : alk. paper) — IS B N 0-292-70964-1 (pbk. : alk. paper)

1. Motion picture authorship. 2. Playwriting. 1. Title.

PN1996.L387 2005

$808.2^{\prime} 3-\mathrm{dc} 22$ 
to my wife, Jeanne

and to John Matthews, mentor 
THIS PAGE INTENTIONALLY LEFT BLANK 